\title{
BMJ Open Euthanasia and physician-assisted suicide not meeting due care criteria in the Netherlands: a qualitative review of review committee judgements
}

\author{
David Gibbes Miller, Scott Y H Kim
}

To cite: Miller DG, Kim SYH. Euthanasia and physicianassisted suicide not meeting due care criteria in the Netherlands: a qualitative review of review committee judgements. BMJ Open 2017;7:e017628. doi:10.1136/ bmjopen-2017-017628

- Prepublication history and additional material for this paper are available online. To view these files, please visit the journal online (http://dx.doi. org/10.1136/bmjopen-2017017628).

Received 4 May 2017 Revised 7 August 2017 Accepted 17 August 2017

CrossMark

Department of Bioethics, National Institutes of Health, Bethesda, Maryland, USA

Correspondence to Dr Scott Y H Kim; scott.kim@nih.gov

\begin{abstract}
To assess how Dutch regional euthanasia review committees (RTE) apply the euthanasia and physicianassisted suicide (EAS) due care criteria in cases where the criteria are judged not to have been met ('due care not met' (DCNM)) and to evaluate how the criteria function to set limits in Dutch EAS practice.

Design A qualitative review using directed content analysis of DCNM cases in the Netherlands from 2012 to 2016 published on the RTE website (https://www. euthanasiecommissie.n//) as of 31 January 2017. Results 0 f 33 DCNM cases identified (occurring 20122016), 32 cases (97\%) were published online and included in the analysis. 22 cases $(69 \%)$ violated only procedural criteria, relating to improper medication administration or inadequate physician consultation. 10 cases $(31 \%)$ failed to meet substantive criteria, with the most common violation involving the no reasonable alternative (to EAS) criterion (seven cases). Most substantive cases involved controversial elements, such as EAS for psychiatric disorders or 'tired of life', in incapacitated patients or by physicians from advocacy organisations. Even in substantive criteria cases, the RTE's focus was procedural. The cases were more about unorthodox, unprofessional or overconfident physician behaviours and not whether patients should have received EAS. However, in some cases, physicians knowingly pushed the limits of EAS law. Physicians from euthanasia advocacy organisations were over-represented in substantive criteria cases. Trained EAS consultants tended to agree with or facilitate EAS in DCNM cases. Physicians and families had difficulty applying ambiguous advance directives of incapacitated patients. Conclusion As a retrospective review of physician selfreported data, the Dutch RTEs do not focus on whether patients should have received EAS, but instead primarily gauge whether doctors conducted EAS in a thorough, professional manner. To what extent this constitutes enforcement of strict safeguards, especially when cases contain controversial features, is not clear.
\end{abstract}

\section{INTRODUCTION}

Euthanasia or physician-assisted suicide (EAS) is legally permitted in the Netherlands under the Termination of Life on Request and Assisted Suicide (Review Procedures) Act of 2002. Under this legislation, EAS performed by physicians is not punishable if it meets
Strengths and limitations of this study

- This is the first in-depth analysis of the euthanasia and physician-assisted suicide 'due care not met' case reports from the Dutch euthanasia review committees.

- $97 \%$ of the due care not met cases from 2012 to 2016 were included in the review.

- Case reports were analysed using directed content analysis by two separate reviewers.

- Case translation may have limited some of the nuances we were able to gather from the case reports.

- This study did not compare 'due care not met' to 'due care met' case reports, and thus cannot draw comparisons between these two types of cases.

statutory due care criteria (see boxes 1 and 2). Furthermore, physicians are required to report all cases of EAS for review by regional euthanasia review committees (RTE committees), which retrospectively assess whether physicians complied with the criteria.

The Dutch EAS system is often cited in debates over EAS legalisation in other jurisdictions. For example, in the 2015 case Carter v. Canada (Attorney General) overturning a federal prohibition on EAS, the Supreme Court cited existing EAS systems, including the system in the Netherlands, as evidence that risks can be minimised with legal safeguards. The Court affirmed the trial judge's opinion that '... the risks of physician-assisted death "can be identified and very substantially minimized through a carefully-designed system" that imposes strict limits that are scrupulously monitored and enforced'. ${ }^{1}$ Evidence for these conclusions consists of quantitative surveys and death certificate reviews, supplemented by subgroup interviews. ${ }^{23}$ For example, a study of EAS patients in the Netherlands from 1990 to 2005 did not in general find disproportionate representation of vulnerable persons. ${ }^{4}$ These studies, however, 
Box 1 Brief background on euthanasia and physicianassisted suicide practice and regulation in the Netherlands

The practice of legally protected euthanasia or physician-assisted suicide (EAS) has been in existence for several decades in the Netherlands, although formal legislation was not enacted until 2002 with the Termination of Life on Request and Assisted Suicide (Review Procedures) Act. ${ }^{44}$ Under the law, the Dutch regional euthanasia review committees (Regionale Toetsingscommissies Euthanasie (RTE)) review all EAS reports to determine whether the notifying physicians (physicians who performed EAS) acted in accordance with the statutory due care criteria laid out in section 2 of the EAS legislation (box 2). The RTE publishes a selection of their reports to provide 'transparency and auditability' of EAS practice and 'to make clear what options the law gives physicians ${ }^{20}$ (p. 4).

In 1997, the Royal Dutch Medical Association formed the Support and Consultation on Euthanasia in the Netherlands (SCEN) to professionalise the process of EAS consultations. ${ }^{42}$ SCEN is a formal network of physicians who are trained to provide independent consultations for physicians receiving EAS requests. ${ }^{42}$ SCEN physicians evaluate patients requesting EAS to determine if the due care criteria are met and provide non-binding reports to the physician performing EAS as a means of improving the quality of EAS practice. They usually serve as the legally required independent physician EAS consultant but can dispense less formal advice and assistance. SCEN receives financial support from the Dutch government. ${ }^{42}$

In March 2012, a new organisation called the End-of-Life Clinic (Levenseindekliniek) began to provide EAS, primarily to patients whose own physicians had declined to perform EAS. It consists of mobile teams made up of a physician and nurse and is funded by Right to Die NL (Nederlandse Vereniging voor een Vrijwillig Levenseinde (Dutch Association for a Voluntary End of Life)), a euthanasia advocacy organisation. ${ }^{45}$

do not provide insight into how the RTEs provide oversight using the due care criteria.

Some Dutch commentators state that the RTEs use the due care criteria to provide 'strict limits' on EAS, pointing to '.. the scrutiny of the committees and their rather rigid evaluations... So it seems, the regulations and procedures work well' ${ }^{5}$ Yet there is an extensive discussion among Dutch doctors and researchers about the difficulty of interpreting some of the due care criteria-especially the unbearable suffering criterion. ${ }^{26} 7$ For example, a study of 2100 Dutch physicians found that, among physicians who had received a request for EAS, 25\% had experienced difficulty with decision making regarding the due care criteria, and in particular with the "unbearable and hopeless suffering' and 'voluntary and well-considered' request criteria. ${ }^{8}$ Despite this difficulty, according to the RTE annual reports, during a period (2002-2016) when there were 49287 cases of EAS in the Netherlands, only 89 cases were found to be due care not met (DCNM), giving a DCNM rate of fewer than 2 cases per $1000(0.18 \%) .{ }^{9-23}$

Because of the Dutch system's commitment to transparency, summaries of RTE decisions for almost all DCNM cases since 2012 are available online. We analysed these cases to address two questions. First, how do the RTE committees interpret and apply the due care criteria
Box 2 Dutch euthanasia and physician-assisted suicide (EAS) due care criteria*

The regional euthanasia review committees (RTE) examine retrospectively whether the attending physician acted in accordance with the statutory due care criteria laid out in section 2 of the Termination of Life on Request and Assisted Suicide (Review Procedures) Act. As stated in the RTE Code of Practice, ${ }^{31}$ (p. 6), these criteria require that a physician performing EAS must:

- be satisfied that the patient's request is voluntary and wellconsidered

- be satisfied that the patient's suffering is unbearable, with no prospect of improvement†

- have informed the patient about his situation and his prognosis

- have come to the conclusion, together with the patient, that there is no reasonable alternative in the patient's situation

- have consulted at least one other, independent physician, who must see the patient and give a written opinion on whether the due care criteria set out in (a) to (d) have been fulfilled

- exercise due medical care and attention in terminating the patient's life or assisting in his suicide.

*The first four criteria pertaining to patient eligibility are called 'substantive' criteria and the last two are called 'procedural' criteria in official government reports and the literature. 82425

tCriteria $a$ and $b$ each have two components that the RTE committees evaluate. These requirements will be treated independently from one another and discussed separately. For example, criterion a consists of the requirement that the EAS request must be voluntary, and the separate requirement that the EAS request must be well-considered. We follow the RTE committees' convention of considering these requirements as distinct judgements.

when making DCNM decisions? Second, what can this information tell us about how the retrospective review system functions as a safeguard in Dutch EAS practice?

\section{METHODS}

We reviewed all EAS DCNM cases that the RTE had published online as of 31 January 2017, which included cases from 2012 to 2016 (https://www.euthanasiecommissie.nl/uitspraken-en-uitleg/o/onzorgvuldig). According to the RTE, there were 10 DCNM cases in 2012, 5 cases in 2013, 4 cases in 2014, 4 cases in 2015 and 10 cases in $2016,{ }^{19-23}$ and all but one of these cases were published on the RTE website. Thus, this study included 97\% (32 of 33) of the DCNM cases from 2012 to 2016.

The cases stated which due care criteria (see box 2) were violated, and we followed the accepted distinction $^{82425}$ between 'substantive' (a through d, pertaining to patient eligibility) and 'procedural' (e and f) criteria to classify the cases. The RTE case reports of cases involving the substantive criteria were quite extensive (average 4101 words) and very detailed in some cases (range 2236-8688 words). The cases involving only procedural criteria were more brief and straightforward (average 2282 words, range 1176-4166). Thus, for the procedural cases, we used online translation tools and as-needed consultations with Dutch-speaking academics to clarify passages; the 10 substantive criteria cases were translated by certified 
Table 1 Characteristics of patients, due care not met cases from 2012 to $2016, n=32$

\begin{tabular}{lcc}
\hline Characteristic & No. & $\%$ \\
\hline Women & 18 & 56 \\
\hline Age group, years* & & \\
\hline $40-50$ & 2 & 6 \\
\hline $50-60$ & 4 & 13 \\
\hline $60-70$ & 9 & 28 \\
\hline $70-80$ & 5 & 16 \\
\hline $80-90$ & 9 & 28 \\
\hline $90+$ & 3 & 9 \\
\hline Substantive criteria case & 10 & 31 \\
\hline EAS advocacy organisation case & 6 & 19 \\
\hline Primary doctor refused to provide EAS & 6 & 19 \\
\hline
\end{tabular}

Number of doctors involved in EAS

\begin{tabular}{|c|c|c|}
\hline 2 & 20 & 63 \\
\hline 3 & 10 & 31 \\
\hline 4 & 2 & 6 \\
\hline \multicolumn{3}{|l|}{ Number of official consultants } \\
\hline 1 & 27 & 84 \\
\hline 2 & 5 & 16 \\
\hline \multicolumn{3}{|l|}{ Number of SCEN consultants } \\
\hline 0 & 2 & 6 \\
\hline 1 & 26 & 81 \\
\hline 2 & 4 & 13 \\
\hline Disagreement between doctors Involved & 5 & 16 \\
\hline
\end{tabular}

*These are categories used in most of the reports. Some 2012 case reports used non-overlapping age categories (eg, 40-49 years). The 2012 cases have been converted to the current format. EAS, euthanasia or physician-assisted suicide; SCEN, Support and Consultation on Euthanasia in the Netherlands.

medical translators through the National Institutes of Health Library's translation services. ${ }^{26}$

The case reports were analysed using a previously described method, ${ }^{26}{ }^{27}$ through directed content analysis $^{28}$ primarily focused on reasons given by the RTEs for why each of the due care criteria had not been met and coding for any emergent themes and patterns. A coding scheme was developed by the authors as they independently read the reports. DGM and SYHK independently coded all of the reports, and discrepancies were resolved through discussion. Data were entered into SPSS software for descriptive analysis only.

\section{RESULTS}

\section{Characteristics of the DCNM cases}

The characteristics of the patients are summarised in table 1 .

The most common diagnosis was cancer $(18 / 32,56 \%)$. Six cases (19\%) involved neurodegenerative diseases, including Alzheimer's disease, Parkinson's disease and
Huntington's disease. There was one case (2014-01) of EAS for psychiatric reasons (bipolar depression). Many patients had more than one medical condition, including stroke, heart failure, tinnitus, vision loss, aphasia and chronic pain, but one patient (2012-17) had no medical condition as a basis for EAS.

Twenty-two of 32 cases $(69 \%)$ failed to meet only procedural criteria, while 10 cases $(31 \%)$ did not meet at least one substantive criterion (see online supplementary file 1). Of the 10 substantive cases, $9(90 \%)$ involved patients with non-cancer diagnoses and in non-terminal states (including Huntington's disease, Parkinson's disease, Alzheimer's disease, psychiatric conditions and past stroke or cerebrovascular incident with stable recovery). In six cases (five substantive and one procedural), the patients relied on EAS advocacy organisations (see box 1) to provide EAS instead of their primary doctors.

\section{Procedural criteria (table 2) \\ Consultation (10/32 cases, $31 \%)$}

The most common reason ( 7 of 10 cases) for not meeting this criterion was lack of independence: the consultant (see box 1) was already familiar with the case, had professional or financial ties to the EAS physician or, in one case (2012-31), the consultant trained by the organisation Support and Consultation on Euthanasia in the Netherlands (SCEN, see box 1) essentially took over a case from the physician. In one case (2016-86), the EAS physician treated the consultation as immaterial, telling the consultant that he would proceed regardless of the evaluation. In another case (2013-106), the time between consultation and EAS implementation was deemed to be too long. The psychiatric EAS case (2014-01) was notable because, despite an independent consultation with a SCEN doctor, the RTE determined that the physician should have obtained a specialist consultation because neither the EAS physician nor the consultant was a psychiatrist.

We examined disagreements between the EAS performing physician and SCEN consultants: cases 2012-33 and 2016-37. In each case, two consultants disagreed about whether the due care criteria had been met. In case 2012-32, the consultant did not find unbearable suffering but expected the patient would eventually have it, and the physician performed EAS without a second consult. In one case (2016-86), the physician pressured the consultant to find the due care criteria met.

In some cases, the consultants were more active than the EAS physicians in facilitating the EAS, in several ways: taking over key aspects of the case (2012-31); directing the physician to refer the patient to an End of Life Clinic physician (see box 1), and then acting as the consultant to that End of Life Clinic physician (2016-21); and 'immediately concluding' that due care criteria were met 'to the (EAS) physician's surprise', advising the physician not to seek further specialty consultations (2014-05). Moreover, in case 2012-17, the physician stated that 'he would not have been convinced to carry out the (EAS) request if he had not received 'permission' from the SCEN physician'. 
Table 2 Procedural due care criteria cases

\begin{tabular}{lll} 
Case ID & $\begin{array}{l}\text { Criteria not } \\
\text { met }\end{array}$ & Patient characteristics \\
\hline 2012-30 & Consultation & $\begin{array}{l}\text { A woman, 80-89 years } \\
\text { old, with Parkinson's } \\
\text { disease, stroke, dysarthria } \\
\text { and incontinence }\end{array}$
\end{tabular}

2012-31 Consultation A woman, 80-89 years old, with rapidly progressing Alzheimer's disease, pain and vision problems

\section{Judgement summary}

GP did not find patient to meet unbearable suffering criterion. Patient turned to Foundation for Voluntary Life (SVL); consultant, also from SVL, was already involved in the case (previously reviewed patient's file and discussed it with the physician), thus was not independent. Consultant also avoided the patient's GP.

GP conscientiously objected. EAS-providing physician inexperienced with EAS referred patient to an experienced SCEN consultant. Physician only evaluated the clinical status of patient, relied on consultant's EAS judgement. Consultant guided physician through EAS and was present for physician exam of patient and during EAS implementation. RTE judged the consultant took over part of the physician's role.

$\begin{array}{lll}\text { 2012-32 Consultation } & \begin{array}{l}\text { A woman, 60-70years old, } \\ \text { with rapidly progressing } \\ \text { lung cancer }\end{array} \\ \text { 2012-38 Medical care } & \begin{array}{l}\text { A man, 60-70years old, } \\ \text { with oesophageal cancer }\end{array}\end{array}$

2012-39 Medical care A woman, 60-70years old, with breast cancer

SCEN consultant and EAS physician in same practice. SCEN doctor did not find unbearable suffering and suggested another consultation, but the physician performed EAS to the SCEN consultant's surprise.

Physician used medications not permitted by the RTE for EAS. He had done this before in 2008 and had agreed to use the standard EAS drugs.

2012-40 Medical care

A man, 60-69years old, with recent metastatic vertebral cancer, with paraplegia

, Physician used less than half of the recommended dose of the comainducing agent and has a previous case in which he made the same error.

Physician administered the barbiturate and the paralytic agent at the same time, rather than inducing the coma first.

2013-103 Consultation A woman, 60-70years old, Consultant was a direct colleague of the EAS physician. with gastric cancer

A woman, 80-90years old, SCEN consultant and the physician were in the same partnership.

2013-104 Consultation A woman, 80-90
with liver cancer

2013-106 Consultation A man, 80-90years old, with COPD, heart failure, renal insufficiency, osteoarthritis, diabetes and depression from wife's death

2013-107 Medical care A man, 70-80years old, with mesothelioma

Consultant found DCNM because the patient was grieving. A psychiatrist then found the patient depressed but competent. The consultation criterion was not met because of the long delay between the first consultation and the EAS.

$\begin{aligned} & \text { 2014-04 Medical care } \text { A woman, 70-80years } \\ & \text { old, with metastatic lung }\end{aligned}$ cancer

Physician used a benzodiazepine as a coma inducer instead of thiopental.

Patient did not die after the physician administered the first set of EAS drugs and had to order another set from a pharmacist, which took 2 hours to arrive.

2015-28 Medical care A man, 80-90years old, with metastatic cancer

Physician used a low dose of the coma inducer and did not perform a coma check.

2015-29 Medical care A woman, 40-50years old, Physician used a low dose of the coma inducer and did not perform a with leukaemia coma check.

2015-81 Medical care A man, 70-80years old, with multiple myeloma

Patient did not die after administration of meds, and physician left the patient to obtain backup meds, then administered the neuromuscular blocker without a second coma inducer, despite evidence that the patient was not in a full coma.

$\begin{array}{lll}\text { 2016-23 Medical care } & \begin{array}{l}\text { A man, 80-90years old, } \\ \text { with Alzheimer's disease }\end{array} & \begin{array}{l}\text { The physician used a phenobarbital beverage instead of pentobarbital } \\ \text { and at too low a dose; thus, had to be followed with intravenous EAS. }\end{array} \\ \text { 2016-24 Medical care } & \begin{array}{l}\text { A man, 60-70years old, } \\ \text { with a distant stroke and a } \\ \text { recent stroke, leaving him } \\ \text { bedridden. }\end{array}\end{array}$




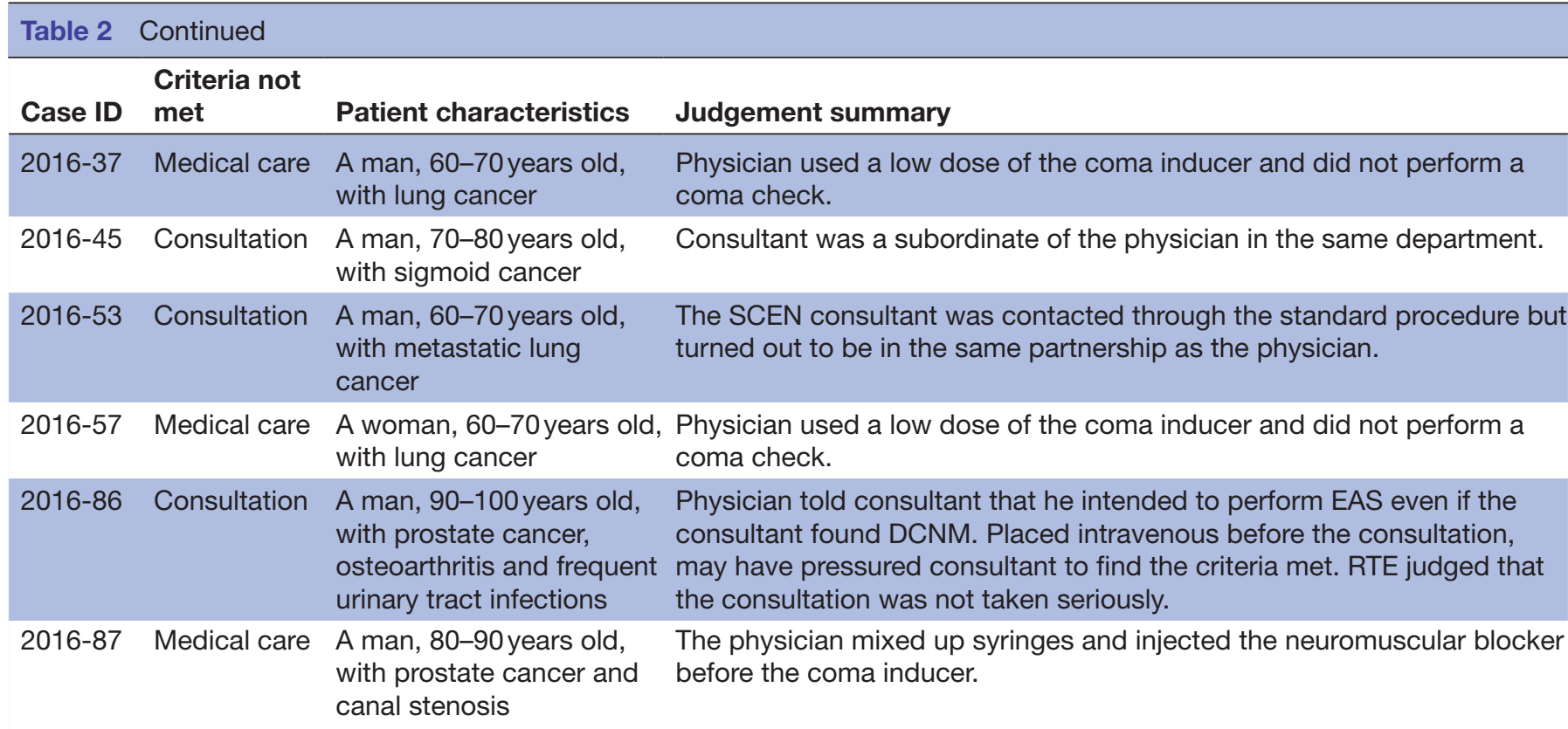

SCEN consultants were trained by the Support and Consultation on Euthanasia in the Netherlands (SCEN) organisation (see box 1). COPD, chronic obstructive pulmonary disease; DCNM, due care not met; EAS, euthanasia and physician-assisted suicide; GP, general practitioner; RTE, regional euthanasia review committees.

\section{Due Medical Care (14/32, 44\%)}

This criterion was most commonly not met because physicians incorrectly used drugs, dosing regimens (too low), route of administration (intramuscular instead of intravenous) or order of administration of EAS drugs (eg, paralytic before sedative). In two cases (2012-38 and 2012-39), the physicians were repeat offenders: they had made similar errors in previous EAS cases. In one case (2016-85), the physician covertly administered a sedative, and the family restrained the resisting patient so that additional EAS agents could be given. In two cases, physicians were not prepared with sufficient medications, and they either left the patient (2015-81) to retrieve more medications or had to order more medication from the pharmacist after initial doses had already been administered (2014-04).

\section{Substantive criteria (table 3 )}

There was one case (2013-91) that did not meet the criterion of informing the patient. In this case, the physician refused to communicate to the RTE most of the key facts of the case, and the RTE therefore deemed all substantive criteria to be not met.

Voluntary $(4 / 32,13 \%)$ and Well-Considered Request (5/32, 16\%) Judgements of voluntariness and the well-considered request were aligned in all but one case (2015-01), in which the RTE deemed the patient's request to be voluntary but not well-considered because she refused a geriatric consultation and thus was deemed not to be fully informed. For the other cases, the reasons the criteria were not met included doubts about the applicability of an incapacitated patient's advance directive (2016-85), the failure of the physician to discuss EAS alone with the patient (2014-01) and concerns about the ability of the physician to interpret the behaviour of an incapacitated patient (2012-08).

\section{Unbearable Suffering (6/32, 19\%)}

In applying the unbearable suffering criterion, the RTE focused on the thoroughness of the physician's evaluation. In case 2014-05 (the woman with tinnitus), the RTE specified that the patient's condition could justify EAS but stated that the physicians' process of evaluation was not thorough. In two other cases (2012-8 and 201402), the RTE doubted that unbearable suffering could be assessed given the patients' communication impairments, pointing out the inappropriateness of inferring from the look in an incapacitated patient's eyes or interpretations of non-verbal and verbal behaviours. In one case (201233) the consultant stated, 'The unbearable nature of her suffering was also apparent from the resolve of her request for euthanasia'. In this case, the RTE did not object to using the EAS request itself as a basis for inferring unbearable suffering, but instead doubted that the physician could have been convinced because the patient was willing to delay EAS for several months. In case 201217 , the reason for DCNM was a matter of legal definition, as the basis of the patient's suffering was not a medical condition.

The RTE's discussion of the unbearable suffering criterion in other cases was instructive as well. In case 201232 , the consultant did not find unbearable suffering, but the RTE stated it could 'deduce' from the physician's report that the patient's suffering became unbearable by the time EAS was actually performed. In two cases (2012-33 and 2014-02), the physician used 'if it were me' 


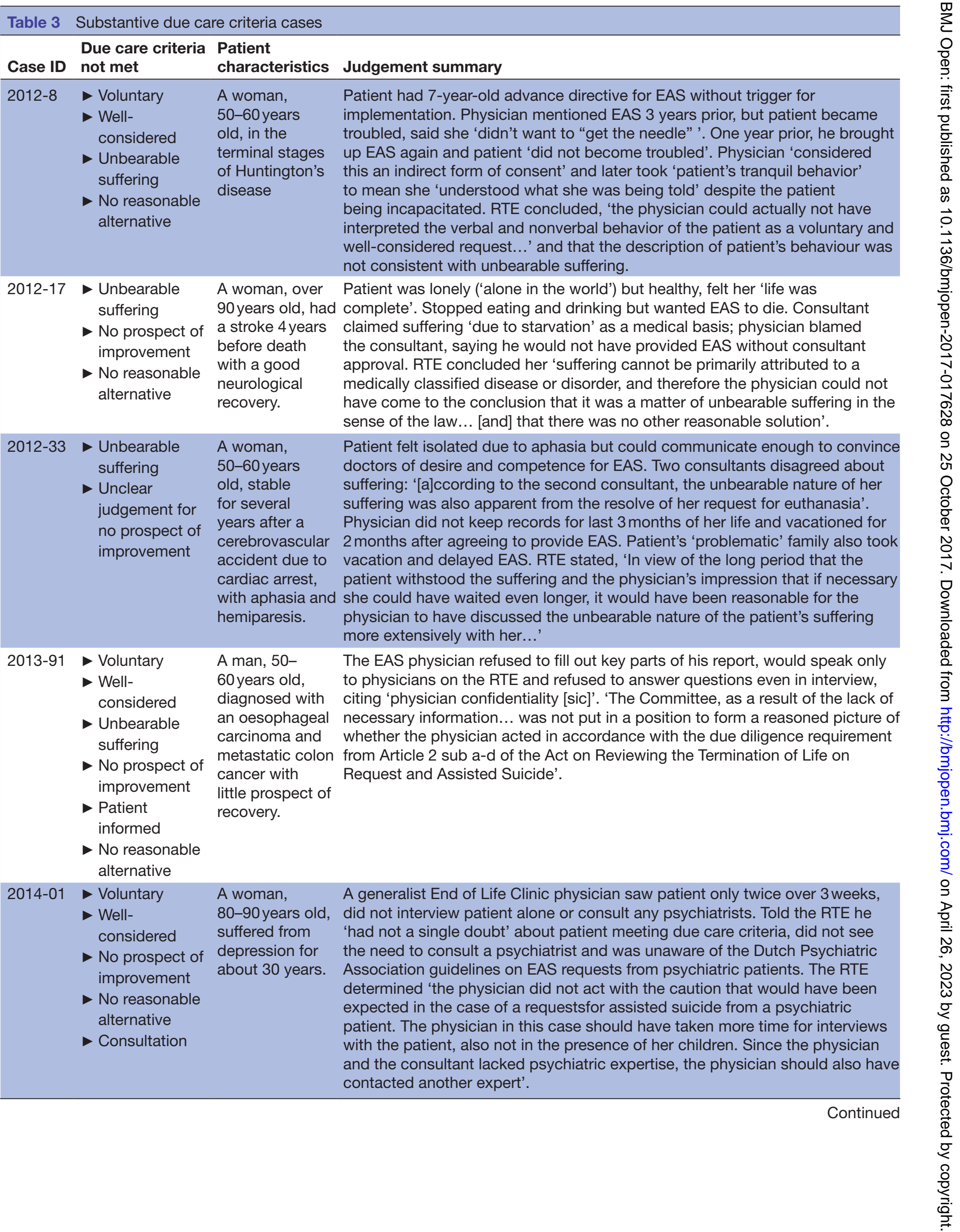




\begin{tabular}{lll} 
Table 3 & Continued \\
\hline & Due care criteria & Patient \\
Case ID & not met & characteristics Judgement summary \\
\hline
\end{tabular}

2014-02 $\begin{gathered}\text { Unbearable } \\ \text { suffering }\end{gathered}$

A woman, 80-90years old, placed in a nursing home after a second cerebrovascular accident that left her with cognitive disorders and aphasia.
Patient not competent, in a $\mathrm{NH}$; had a 20 -year-old advance directive, which she confirmed orally to her physician that requested EAS if she were permanently placed in $\mathrm{NH}$. $\mathrm{NH}$ doctor noted patient to be a 'quiet and friendly woman', refused children's request for EAS; children turned to End of Life Clinic. The Clinic doctor saw patient twice. Consultant saw in '[the patient's] eyes... quite clearly her despair and unhappiness' but also said it was a 'very difficult case, and that the limits of the law would be sought here'. Physician 'did not see any signs of unbearable suffering in the patient and based his decision exclusively on the fact that the patient was placed in a nursing home...' RTE concluded that 'The mere fact that the patient permanently had to leave her own environment and be admitted to a nursing home is insufficient to assume that the suffering is unbearable... the physician-merely on the basis of the picture of the patient that was outlined to him-expended insufficient time and effort in this situation to confirm the unbearable nature of the patient's suffering'.

\begin{tabular}{|c|c|c|c|}
\hline 2014-05 & $\begin{array}{l}\text { Unbearable } \\
\text { suffering } \\
\text { No prospect of } \\
\text { improvement } \\
\text { No reasonable } \\
\text { alternative }\end{array}$ & $\begin{array}{l}\text { A woman, } \\
40-50 \text { years old, } \\
\text { with tinnitus for } \\
\text { more than } 10 \\
\text { years, severe } \\
\text { hyperacusis } \\
\text { and neuralgia; } \\
\text { had history } \\
\text { of psychiatric } \\
\text { disorders } \\
\text { including } \\
\text { anorexia, post } \\
\text { traumatic stress } \\
\text { disorder, anxiety } \\
\text { and depression. }\end{array}$ & $\begin{array}{l}\text { Patient had history of not following physician advice and had halted EAS } \\
\text { evaluation process several times. End of Life Clinic psychiatrist wrote a triage } \\
\text { report } 6 \text { months prior and did not address psychiatric issues. SCEN consultant } \\
\text { surprised End of Life Clinic physician by saying no further evaluation needed } \\
\text { and told RTE that 'she wanted to prevent the patient from having to go through } \\
\text { another interview with an independent psychiatrist'. Consultant contacted } \\
\text { triage doctor 'twice to insist that she supplement the report with conclusions } \\
\text { regarding DSM Axis I and Axis II based on the triage'. RTE was sceptical of } \\
\text { this retroactive 'supplement'. RTE determined the End of Life Clinic physician } \\
\text { 'lacked a clear somatic diagnosis and... the physician... should have had a } \\
\text { psychiatric examination performed...especially since the physician initially } \\
\text { had a 'fishy' feeling about this request... The physician conducted inadequate } \\
\text { research on the existence of real options to ease the patient's suffering...' }\end{array}$ \\
\hline 2015-01 & $\begin{array}{l}\text { Well- } \\
\text { considered } \\
\text { request } \\
\text { No prospect of } \\
\text { improvement } \\
\text { No reasonable } \\
\quad \text { alternative }\end{array}$ & $\begin{array}{l}\text { A woman, } \\
\text { over } 90 \text { years } \\
\text { old, with many } \\
\text { non-terminal } \\
\text { conditions } \\
\text { including } \\
\text { macular } \\
\text { degeneration, } \\
\text { intestinal } \\
\text { problems, } \\
\text { back pain and } \\
\text { dysphasia. }\end{array}$ & $\begin{array}{l}\text { Patient went to End of Life Clinic when her own doctor refused EAS. Patient } \\
\text { refused examination by the clinic physician. The consultant did not think } \\
\text { the request was well considered or the condition futile and recommended } \\
\text { geriatric consult, but the patient refused. End of Life Clinic physician eventually } \\
\text { convinced the consultant to change this decision. 'The Committee is of the } \\
\text { opinion [that the physician] too easily went along with the patient's refusal to } \\
\text { be examined by a geriatrician'. }\end{array}$ \\
\hline 2016-21 & $\begin{array}{l}\text { No prospect of } \\
\text { improvement } \\
\text { No reasonable } \\
\text { alternative }\end{array}$ & $\begin{array}{l}\text { A man, } \\
50-60 \text { years } \\
\text { old, with mild } \\
\text { Parkinson's } \\
\text { disease and } \\
\text { psychiatric } \\
\text { issues related to } \\
\text { coping. }\end{array}$ & $\begin{array}{l}\text { Treating psychiatrist and neurologist thought a psychological component } \\
\text { played a role in patient's suffering. Family physician reluctant but consulted } \\
\text { SCEN doctor who initially thought not hopeless but told family physician } \\
\text { to refer patient to End of Life Clinic. Clinic physician saw patient twice } \\
\text { within a week, consulted same SCEN doctor and without consulting new } \\
\text { specialists deemed patient's condition futile, contrary to what the previous } \\
\text { specialists stated. Committee stated, 'The physician was not obligated to } \\
\text { further scrutinize the advice of the treating neurologist and the judgment of } \\
\text { the psychiatrist other than to make accurate record of them. The physician, } \\
\text { to reach a well-considered judgment of the hopelessness of the suffering } \\
\text { and any treatment alternatives, must consult with the neurologist and the } \\
\text { psychiatrist or another specialist expert in this field... The physician had to use } \\
\text { this deliberation to check his own judgement against that of the above-named } \\
\text { specialists'. }\end{array}$ \\
\hline
\end{tabular}

Continued 


\begin{tabular}{|c|c|c|c|}
\hline Case ID & $\begin{array}{l}\text { Due care criteria } \\
\text { not met }\end{array}$ & $\begin{array}{l}\text { Patient } \\
\text { characteristics }\end{array}$ & Judgement summary \\
\hline
\end{tabular}

SCEN consultants were trained by the Support and Consultation on Euthanasia in the Netherlands (SCEN) organisation (see box 1). EAS, euthanasia and physician-assisted suicide; $\mathrm{NH}$, nursing home; RTE, regional euthanasia review committees.

reasoning. For example, 2012-33 states, 'For the physician, the crucial question was whether, if he were in the patient's position, he would find the suffering unbearable and what he would want then'. This reasoning did not draw critical comments from the RTE.

\section{No Prospect of Improvement $(6 / 32,19 \%)$ and No Reasonable} Alternative $(7 / 32,22 \%)$

These two criteria were the substantive criteria that were most commonly found to be not met (and occurred together in all cases but one). In one case of a Huntington's patient (2012-08), the RTE deemed nursing home care to be a reasonable alternative because there was no clear trigger for implementing EAS stated in the advance directive. Other reasons for not meeting these futility criteria included the non-medical source of suffering (2012-17), lack of adequate reporting (2013-91), lack of a psychiatric consult for a patient (2014-01 and 2014-05), failure of the physician to critically consider a patient's refusal for further evaluation (2015-01) and physician rejection (without explanation) of the opinions of specialists who deemed that the patient did have reasonable alternatives (2016-21).

\section{Unusual behaviours of physicians}

Some of the behaviours of doctors (both EAS-providing physicians and consultants) formed the basis for DCNM judgements and were notably unusual, perhaps even unprofessional. In case 2012-33, the physician did not keep medical records for the last 3 months of the patient's life. The physician in case 2013-91 refused to fill out key parts of the report form, refused to be interviewed by non-physicians on the RTE and refused to answer key questions in person, citing patient confidentiality (despite the fact that many details were included in the consultant's report). In case 2015-01, the physician saw the patient only twice and did not examine the patient before proceeding to EAS. This physician also persuaded the consultant to revise his report with a due care met (DCM) judgement, and he did not initially fully report to the RTE his EAS discussions with the patient. In case 2014-05, a psychiatrist, who had seen the patient 6 months before death for an End of Life Clinic triage interview, complied with the SCEN consultant's request to amend the patient's medical record with psychiatric conclusions without seeing the patient again for a psychiatric evaluation. Finally, in case 2016-86, the physician, intending to perform EAS regardless of the consultation outcome, inserted an intravenous line in the patient even before the consultant arrived.

Some due medical care violations involved unusual or unprofessional behaviours, such as the physician leaving the patient during EAS to obtain backup drugs (2015-81), the physician ordering backup EAS drugs from a pharmacist after administering the first set (2014-04) and the physician injecting the EAS drugs intramuscularly instead of intravenously, despite explicit guidance to the contrary, because the physician did not want the patient's family to see blood or an intravenous placement (2016-24).

\section{Pushing the legal boundaries}

In several cases, there were indications that the physicians or consultants involved were aware they were pushing the legal boundaries in performing EAS. In case 2014-02, the consultant 'realised that it was a very difficult case, and that the limits of the law would be sought here'. In case 2016-85, in which the patient was surreptitiously given sedatives and later held down in order to administer more 
drugs, the physician justified her actions, saying that she would have performed EAS 'even if the patient had said at that moment: "I don't want to die" '. The physician 'highlighted the need for transparency in this case' with the reasoning that 'EAS might occur more frequently in incompetent patients'.

In case 2012-8, 'The physician declared that it did not surprise her when she was invited for an interview with the [RTE] Committee. The consultant had mentioned the possibility to her'. Moreover, in case 2012-17, the physician seemed to be aware of pushing the boundaries, as he "confirmed... there was actually no question of a disease or disorder' in the patient, while stating that he would not have performed EAS if the SCEN consultant had not granted 'permission'.

\section{Prominence of EAS advocacy organisations}

In six cases $(6 / 32,19 \%)$, physicians from EAS advocacy organisations provided EAS. The Voluntary Life Foundation $^{29}$ provided EAS in the procedural case 2012-30. In the other five cases, the End of Life Clinic ${ }^{30}$ provided EAS, and all five cases involved substantive criteria. Thus, the End of Life Clinic provided EAS for 5 of the 10 substantive criteria cases in this study (50\%). In 2016-21, the family physician referred the patient to the End of Life Clinic at the SCEN consultant's suggestion.

In three cases involving the End of Life Clinic (201401, 2014-05 and 2016-21), the RTE determined that the physicians should have consulted with specialists (psychiatrists or neurologists). Additionally, in case 2015-01, the RTE determined that the End of Life Clinic physician too easily accepted the patient's refusal of a geriatric evaluation. The RTE explicitly stated in two cases (2014-01 and 2014-02) that the End of Life Clinic physicians spent too little time evaluating the patients, and in case 2014-05, the RTE mentioned that the physician spent too little time researching alternatives to EAS.

\section{DISCUSSION}

Debates over the legalisation of EAS often draw on evidence from the Netherlands to consider how laws can be tailored and enforced to create safeguards to abuse, neglect or errors. ${ }^{1}$ Studies of the Dutch EAS system have found little evidence of abuse $\mathrm{e}^{2-4}$ and praise the 'scrutiny' of the 'rather rigid evaluations'. ${ }^{5}$ However, Dutch physicians also report difficulty in applying the EAS laws and specifically in evaluating the substantive due care criteria. ${ }^{2}{ }^{6-8}$ Despite this difficulty, very few cases are deemed not to meet the due care criteria $(0.18 \%$ of the 49287 cases between 2002 and 2016). ${ }^{9-23}$ Our review of DCNM cases analysed how the RTE interprets and applies the due care criteria, with a specific interest in how the criteria function as safeguards. There were several notable findings.

First, the majority of cases did not meet the due care criteria for procedural or technical reasons. Sixty-nine per cent (22/32) of DCNM cases failed to meet only the procedural due care criteria (due medical care and consulting an independent physician). These criteria are more clearly operationalised than other criteria and do not require extensive interpretation. However, even when the substantive criteria were at issue, the RTE's focus was generally not on whether the physician made a 'correct' judgement, but on whether the physician followed a thorough process (ie, whether physicians should have consulted specialists or evaluated the patient further, but not whether the patient should have received EAS). Indeed, in one case (2012-32), the RTE committee stated it could 'deduce' the presence of unbearable suffering at the time of death, even though the consultant determined that the criterion was not met. In another case (2014-05), the RTE specified that the patient's condition (tinnitus and hyperacusis) could justify EAS but stated that the physicians' process of evaluation was not thorough.

The RTE may focus on procedural aspects of EAS because the review process is retrospective and based on physician self-reporting and perhaps because the RTE committees seriously consider the wording of the EAS law, which is written from the perspective of physicians (ie, whether the physician is 'satisfied' (see box 2) ${ }^{31}$ In other words, the criteria are designed and applied to evaluate the procedures doctors follow (taking 'due care') and not to directly assess the actual eligibility of the patients; they appear designed to determine 'was the doctor careful?' more than 'was EAS appropriate in that case?' This interpretation is supported by the RTE's public statement that the purpose of the EAS legislation is: '1. to create legal certainty for doctors caught in conflicting obligations, 2. to provide transparency in the practice of euthanasia and public scrutiny, and 3. to safeguard, monitor and promote the care with which medical decisions about termination of life on request are taken and the quality of such decisions by bringing matters into the open and applying uniform criteria in assessing every case in which a doctor terminates life' ${ }^{32}$

Given that the RTE tends to focus on the process of EAS (even for the substantive criteria), it is not surprising that many of the DCNM cases involved physicians behaving in seemingly unorthodox or unprofessional ways. Examples of these behaviours included inadequate record keeping, repeated failures to follow standard medical procedures, incompetent use of medications and unusual interpretations of patient confidentiality. The RTE was especially sensitive to incompetent use of medications given its potential to cause unnecessary suffering.

Second, despite the RTE's procedural focus (eg, DCNM because of lack of thoroughness), in some cases it was possible to infer that actual norms were violated, especially in cases where physicians were knowingly pushing the limits of the law. In the case in which the EAS physician noted that there was no medical basis (2012-17), it seems unlikely that the consultant was unaware of the law's boundaries. The doctor who performed EAS on an incapacitated woman by surreptitiously administering a sedative and restraining her to administer additional EAS agents (case 2016-85) had intended to set a precedent 
for other similar EAS cases that she anticipated would become more frequent.

Physicians pushing the limits of EAS laws may reflect the fact that some doctors are also advocates of EAS. This could also explain why one procedural case and half ( 5 of 10) of substantive DCNM cases were performed by physicians affiliated with EAS advocacy organisations, despite the fact that the organisations account for a small proportion of EAS cases in the Netherlands (the End of Life Clinic was involved in less than $5 \%$, or $1219 / 25930$, of EAS cases in the Netherlands from 2012 to 2016). ${ }^{19-23}$ Since the End of Life Clinic does focus on patients whose EAS requests are denied, this over-representation may reflect the complexity of those cases. However, it may also indicate that physicians from the End of Life Clinic interpret and apply EAS laws more flexibly than the RTE.

Third, several cases involved EAS for incapacitated patients. In these cases, determining whether the criteria were met was complicated. Advance directive EAS clauses without clear triggers for EAS implementation leave ambiguity regarding what constitutes a 'request for EAS' and unbearable suffering in a patient who cannot communicate.

Fourth, the role of the SCEN doctors in DCNM cases was unexpected. They are specially trained and knowledgeable about the due care criteria. Thus, we anticipated that DCNM cases would generally involve EAS physicians going against the SCEN consultants' recommendations. Indeed, we did find two cases of this (2012-32 and 2016-86), but in most cases, the consultants either agreed with the EAS physician or played a more active role in facilitating the EAS. This seems consistent with the finding that general practitioners may interpret the law more restrictively than experienced consultants or RTE members. ${ }^{33}$ This dynamic may also explain why so few EAS cases are found as DCNM: if SCEN consultants and RTE committees do not interpret the EAS law as restrictively as general practitioners, then SCEN consultants will infrequently object to EAS, and the RTE committees will be unlikely to find cases to be DCNM.

Fifth, nearly all substantive DCNM cases (9 out of 10) involved non-cancer, non-terminal conditions. Most of these cases had features that are often debated in the literature: EAS for psychiatric disorders or for 'tired of living', in incapacitated patients or by physicians affiliated with EAS advocacy organisations.

What lessons might be drawn from these findings? Specifically, what do these cases tell us about why there are so few DCNM cases and whether the Dutch system provides truly strict safeguards? The two questions are closely related. If the review system sets strict limits and provides scrupulous monitoring, then the extremely low rates of non-compliance would indicate a major achievement in preventing abuses and errors. An alternative explanation is that the rates are low because the system is not designed to, or cannot, provide such strict oversight.

Evaluating patients' EAS requests requires complicated judgements in implementing criteria that are intentionally open-ended, evolving and fraught with acknowledged interpretive difficulties. ${ }^{26-8} 25$ Our review suggests that the Dutch review system's primary mode of handling this difficulty is a trust-based system that focuses on the procedural thoroughness and professionalism of physicians. It is notable that even within this physician-centred system, over $20 \%$ of EAS cases are unreported. ${ }^{34}$ It is difficult to assess what happens in those cases, but it may be that physicians performing questionable cases would have an incentive not to report (unless of course the physician wishes to set a precedent) or to interpret what they are doing as not needing to be reported.

It is striking that 9 out of 10 substantive cases involved non-terminally ill patients, and most contained controversial features such as EAS for psychiatric or 'tired of living' complaints, in incapacitated patients or by physicians sponsored by EAS advocacy organisations. (The one substantive criteria case involved a patient with cancer whose physician refused to cooperate and thus did not meet any substantive criteria.) The Dutch EAS review system was implemented in the 1990s when such cases were rare. Thus, our review raises the question of whether a retrospective, trust-based review system can adequately address these new and controversial developments.

There are important limitations of our study. First, we had to rely on case translations that combined professional medical translators with online translation services. This may have limited some of the nuanced detail we were able to gather from the cases. Additionally, we did not perform a comparative study between the DCM and the DCNM cases, so we cannot draw any firm conclusions about how the criteria are used and reviewed in due care met cases. For instance, it may be that the DCNM rates are low because doctors already rule out questionable cases by refusing. ${ }^{35}$ This seems unlikely since one survey of Dutch general practitioners found an EAS refusal rate of only about $12 \%$ (which may include refusals for conscience reasons). ${ }^{35}$ Since at least $12 \%-17 \%$ of Dutch doctors oppose EAS per se, refusals for non-conscientious reasons is likely quite low. ${ }^{36}$ Thus, the possibility that Dutch doctors are exceptionally good at weeding out ineligible cases among all requests is probably not the primary explanation for the low DCNM rate of less than 2 in 1000.

\section{CONCLUSION}

The Dutch EAS cases judged to be DCNM generally fit three categories. First, most cases are violations of procedural criteria that do not require extensive interpretation by the RTE (the consultation and due medical care criteria). These make up the majority of the cases. Second, even violations of substantive (ie, eligibility) criteria are generally about procedural inadequacies of physicians (reflected in their unusual, unprofessional or overconfident behaviours), rather than directly about the eligibility characteristics of patients. Third, some cases result from doctors pushing the boundaries of EAS law. Other features of DCNM cases are that in general 
the SCEN consultants either agreed with or facilitated these EAS cases and that there was a high representation of physicians from euthanasia advocacy organisations. Finally, virtually all violations of substantive criteria were cases with controversial features.

What can jurisdictions considering EAS laws learn from these findings? The Dutch review system places tremendous trust in its physicians. As one official Dutch report of EAS practice noted, 'the review process is generally based on appreciation of the expertise and professionalism of the physician and the consultant'. ${ }^{38}$ This trust, for the most part, is reciprocated by physicians and consultants, as shown by their transparency in the self-reports (ie, physicians admitting that they knew they were pushing the boundaries and describing even disturbing behaviours). This culture of trust in the authorities that regulate the EAS system is likely supported by the awareness that no doctor under the current law has suffered any legal consequences for reporting cases that do not conform to the due care criteria.

Whether an EAS oversight system based on mutual trust would translate into a system with 'strict limits' in other jurisdictions is an important point for discussion. In jurisdictions considering EAS laws, debates over how best to regulate the practice should focus on the goals of an oversight system. If the primary objective is to directly oversee that only truly eligible patients are receiving EAS, then a prospective independent assessment system (as has been proposed in the $\mathrm{UK}^{39}$ ) may be more fitting than a system that entrusts the physicians to apply difficult-to-interpret criteria and to self-judge whether their cases are reportable, without any serious consequences for violations. In the Netherlands, the data appear to raise questions about whether a trust-based retrospective review system provides adequate oversight for particularly vulnerable patients (such as psychiatric patients and incapacitated patients), especially when the EAS physician is sponsored by an advocacy organisation.

Contributors DGM and SYHK made substantial contributions to the design of the work and the acquisition, analysis and interpretation of data; drafting the work or revising it critically for important intellectual content; and final approval of the version to be published, and agreed to be accountable for all aspects of the work in ensuring that questions related to the accuracy or integrity of any part of the work are appropriately investigated and resolved.

Funding This research was supported in part by the Intramural Research Program of the National Institutes of Health Clinical Center. The study sponsor played no role in the conduct of this study. This research was conducted independently from the funders.

\section{Competing interests None declared.}

Provenance and peer review Not commissioned; externally peer reviewed.

Data sharing statement All data analysed are currently publicly available.

Open Access This is an Open Access article distributed in accordance with the Creative Commons Attribution Non Commercial (CC BY-NC 4.0) license, which permits others to distribute, remix, adapt, build upon this work non-commercially, and license their derivative works on different terms, provided the original work is properly cited and the use is non-commercial. See: http://creativecommons.org/ licenses/by-nc/4.0/

(C) Article author(s) (or their employer(s) unless otherwise stated in the text of the article) 2017. All rights reserved. No commercial use is permitted unless otherwise expressly granted.

\section{REFERENCES}

1. Judgments of the Supreme Court of Canada. Carter v. Canada (Attorney General). 2015 SCC5. 2015 https://scc-csc.lexum.com/ scc-csc/scc-csc/en/item/14637/index.do (accessed 14 Mar 2017).

2. Rietjens JA, van der Maas PJ, Onwuteaka-Philipsen BD, et al. Two Decades of Research on Euthanasia from the Netherlands. What Have We Learnt and What Questions Remain? J Bioeth Inq 2009;6:271-83.

3. Norwood F, Kimsma G, Battin MP. Vulnerability and the 'slippery slope' at the end-of-life: a qualitative study of euthanasia, general practice and home death in The Netherlands. Fam Pract 2009;26:472-80.

4. Battin MP, van der Heide A, Ganzini L, et al. Legal physicianassisted dying in Oregon and the Netherlands: evidence concerning the impact on patients in "vulnerable" groups. J Med Ethics 2007;33:591-7

5. Kimsma GK. Death by request in The Netherlands: facts, the legal context and effects on physicians, patients and families. Med Health Care Philos 2010;13:355-61.

6. Pasman HR, Rurup ML, Willems DL, et al. Concept of unbearable suffering in context of ungranted requests for euthanasia: qualitative interviews with patients and physicians. BMJ 2009;339:b4362.

7. Hanssen-de Wolf JE, Pasman HR, Onwuteaka-Philipsen BD. How do general practitioners assess the criteria for due care for euthanasia in concrete cases? Health Policy 2008;87:316-25.

8. Buiting HM, Gevers JK, Rietjens JA, et al. Dutch criteria of due care for physician-assisted dying in medical practice: a physician perspective. J Med Ethics 2008;34:e12.

9. Regional Euthanasia Review Committees. The Hague, The Netherlands. Annual report, 2002. https://www.euthanasiecommissie. $\mathrm{nl} /$ uitspraken/jaarverslagen/2002/nlendufr/nlendufr/jaarverslag-2002. (accessed 19 Sep 2016).

10. Regional Euthanasia Review Committees. The Hague, The Netherlands. Annual report, 2003. https://www.euthanasiecommissie. nl/uitspraken/jaarverslagen/2003/nl-en-du/nl-en-du/jaarverslag-2003. (accessed 19 Sep 2016)

11. Regional Euthanasia Review Committees. The Hague, the Netherlands. Annual report, 2004. https://www.euthanasiecommissie. $\mathrm{nl} /$ uitspraken/jaarverslagen/2004/nl-en-du-fr/nl-en-du-fr/jaarverslag2004. (accessed 19 Sep 2016).

12. Regional Euthanasia Review Committees. The Hague, The Netherlands. Annual report, 2005. https://www.euthanasiecommissie. $\mathrm{nl} /$ uitspraken/jaarverslagen/2005/nl-en-du-fr/nl-en-du-fr/jaarverslag2005. (accessed 19 Sep 2016).

13. Regional Euthanasia Review Committees. The Hague, The Netherlands. Annual report, 2006. https://www.euthanasiecommissie. $\mathrm{nl} /$ uitspraken/jaarverslagen/2006/nl-en-du-fr/nl-en-du-fr/jaarverslag2006. (accessed 19 Sep 2016).

14. Regional Euthanasia Review Committees. The Hague, The Netherlands. Annual report, 2007. https://www.euthanasiecommissie. nl/uitspraken/jaarverslagen/2007/nl-en-du-fr/nl-en-du-fr/jaarverslag2007. (accessed 19 Sep 2016).

15. Regional Euthanasia Review Committees. The Hague, The Netherlands. Annual report, 2008. https://www.euthanasiecommissie. $\mathrm{nl} /$ uitspraken/jaarverslagen/2008/nl-en-du-fr/nl-en-du-fr/jaarverslag2008. (accessed 19 Sep 2016).

16. Regional Euthanasia Review Committees. The Hague, The Netherlands. Annual report, 2009. https://www.euthanasiecommissie. nl/uitspraken/jaarverslagen/2009/nl-en-du-fr/nl-en-du-fr/jaarverslag2009. (accessed 19 Sep 2016).

17. Regional Euthanasia Review Committees. The Hague, The Netherlands. Annual report, 2010. https://www. euthanasiecommissie.nl/de-toetsingscommissies/uitspraken/ jaarverslagen/2010/nl-en-du-fr/nl-en-du-fr/jaarverslag-2010. (accessed 19 Sep 2016).

18. Regional Euthanasia Review Committees. The Hague, The Netherlands. Annual report, 2011. https://www.euthanasiecommissie. $\mathrm{nl} /$ de-toetsingscommissies/uitspraken/jaarverslagen/2011/nl-en-dufr/nl-en-du-fr/jaarverslag-2011. (accessed 19 Sep 2016).

19. Regional Euthanasia Review Committees. The Hague, The Netherlands. Annual report, 2012. https://www.euthanasiecommissie. nl/uitspraken/jaarverslagen/2012/nl-en-du-fr/nl-en-du-fr/jaarverslag2012. (accessed 19 Sep 2016).

20. Regional Euthanasia Review Committees. The Hague, The Netherlands. Annual report, 2013. https://www.euthanasiecommissie. nl/uitspraken/jaarverslagen/2013/nl-en-du-fr/nl-en-du-fr/jaarverslag2013. (accessed 19 Sep 2016).

21. Regional Euthanasia Review Committees. The Hague, The Netherlands. Annual report, 2014. https://www.euthanasiecommissie. $\mathrm{nl} /$ de-toetsingscommissies/uitspraken/jaarverslagen/2014/nl/nl/ jaarverslag-2014. (accessed 19 Sep 2016). 
22. Regional Euthanasia Review Committees. The Hague, The Netherlands. Annual report, 2015. https://www.euthanasiecommissie. nl/de-toetsingscommissies/uitspraken/jaarverslagen/2015/april/26/ jaarverslag-2015. (accessed 19 Sep 2016).

23. Regional Euthanasia Review Committees. The Hague, The Netherlands. Annual report, 2016. https://www.euthanasiecommissie. nl/uitspraken/jaarverslagen/2016/april/12/jaarverslag-2016. (accessed 25 Apr 2017).

24. Onwuteaka-Philipsen BD, Gevers JKM, van der Heide A, et al. Third Evaluation: Termination of Life on Request and Assisted Suicide. ZonMw: The Hague, 2017. https://www.euthanasiecommissie.nl/ uitspraken/jaarverslagen/2016/april/12/jaarverslag-2016. (accessed 25 Apr 2017)

25. Onwuteaka-Philipsen BD, Gevers JKM, van der Heide A, et al. Evaluation: Termination of Life on Request and Assisted Suicide. ZonMw: The Hague, 2007. https://www.euthanasiecommissie.nl/ uitspraken/jaarverslagen/2016/april/12/jaarverslag-2016. (accessed 25 Apr 2017)

26. Kim SY, De Vries RG, Peteet JR. Euthanasia and Assisted Suicide of Patients With Psychiatric Disorders in the Netherlands 2011 to 2014. JAMA Psychiatry 2016;73:362-8.

27. Doernberg SN, Peteet JR, Kim SY. Capacity Evaluations of Psychiatric Patients Requesting Assisted Death in the Netherlands. Psychosomatics 2016;57:556-65.

28. Hsieh HF, Shannon SE. Three approaches to qualitative content analysis. Qual Health Res 2005;15:1277-88.

29. SLK Stichting Vrijwillig Leven doneert aan Levenseindekliniek. Levenseinde Klin. 2015 http://www.levenseindekliniek.nl/blog/2015/ 05/13/stichting-vrijwillig-leven-doneert-aan-levenseindekliniek/ (accessed 16 Mar 2017).

30. Levenseindekliniek. https://www.levenseindekliniek.nl/en/ (accessed 23 Feb 2017).

31. Regional Euthanasia Review Committees. Code of Practice. The Netherlands: The Hague, 2015. https://www.euthanasiecommissie. $\mathrm{nl} /$ de-toetsingscommissies/uitspraken/brochures/brochures/code-ofpractice/1/code-of-practice. (accessed 19 Sep 2016).

32. Regionale Toetsingscommissies Euthanasie. Euthanasia: $Q$ and A: the termination of life on request and assisted suicide (review procedures) act in practice. $2016 \mathrm{https}: / / \mathrm{www}$.euthanasiecommissie. $\mathrm{nl} /$ uitspraken/publicaties/faq-engels/faq/faq/frequently-askedquestions (accessed 28 Feb 2017).

33. Rietjens JA, van Tol DG, Schermer M, et al. Judgement of suffering in the case of a euthanasia request in The Netherlands. J Med Ethics 2009;35:502-7.
34. Onwuteaka-Philipsen BD, Brinkman-Stoppelenburg A, Penning C, et al. Trends in end-of-life practices before and after the enactment of the euthanasia law in the Netherlands from 1990 to 2010: a repeated cross-sectional survey. The Lancet 2012;380:908-15.

35. Jansen-van der Weide MC, Onwuteaka-Philipsen BD, van der Wal G. Granted, undecided, withdrawn, and refused requests for euthanasia and physician-assisted suicide. Arch Intern Med 2005; 165:1698-704.

36. Kouwenhoven PS, Raijmakers NJ, van Delden JJ, et al. Opinions of health care professionals and the public after eight years of euthanasia legislation in the Netherlands: a mixed methods approach. Palliat Med 2013;27:273-80.

37. Rietjens JA, van der Heide A, Onwuteaka-Philipsen BD, et al. A comparison of attitudes towards end-of-life decisions: survey among the Dutch general public and physicians. Soc Sci Med 2005:61:1723-32.

38. van der Heide A, Legemaate J, Onwuteaka-Philipsen B, et al. Second Evaluation: Termination of Life on Request and Assisted Suicide. ZonMw: The Hague, 2012. https://www.rijksoverheid.nl/ documenten/rapporten/2012/12/18/tweede-evaluatie-wet-toetsinglevensbeeindiging-op-verzoek-en-hulp-bij-zelfdoding. (accessed 25 Apr 2017).

39. Marris R. Assisted Dying (No. 2) Bill 2015-16. http://services. parliament.uk/bills/2015-16/assisteddyingno2.html (accessed 1 Aug 2017).

40. Griffiths J, Weyers H, Adams M. Euthanasia and Law in Europe. 2nd edt. Portland: Hart Publishing, 2008.

41. Van Wesemael Y, Cohen J, Onwuteaka-Philipsen BD, et al. Establishing specialized health services for professional consultation in euthanasia: experiences in the Netherlands and Belgium. BMC Health Serv Res 2009;9:220.

42. Jansen-van der Weide MC, Onwuteaka-Philipsen BD, van der Wal G. Quality of consultation and the project 'Support and Consultation on Euthanasia in the Netherlands' (SCEN). Health Policy 2007;80:97-106.

43. Levenseindekliniek. Euthanasia in the Netherlands. https://www. levenseindekliniek.nl/en/euthanasia-in-the-netherlands/. (accessed 28 Feb 2017).

44. Sheldon T. Mobile "life's end" teams start work in Netherlands. BMJ 2012;344:e1681.

45. Snijdewind MC, Willems DL, Deliens L, et al. A Study of the First Year of the End-of-Life Clinic for Physician-Assisted Dying in the Netherlands. JAMA Intern Med 2015;175:1633-40. 